\title{
НЕКОТОРЫЕ АСПЕКТЫ ПОВЫШЕНИЯ ДОСТОВЕРНОСТИ ДИНАМИЧЕСКОГО АНАЛИЗА.
}

Онищенко С.A.

\section{(ЗАО "Повярная геофизическая экспедииия")}

Рассмотрены вопросы связи амплитудных искажений сейсмической записи со сложным строением ВЧР и пути повышения точности результатов динамического анализа на основе найденных корреляционнњх связей.

Главным фактором, влияющим на структурные и динамические характеристики зарегистрированного поля отраженных волн, является изменчивость ВЧР (верхней части разреза). На современном этапе сейсморазведочныт исследований под ВЧР понимают самый первый от дневной поверхности слой геологического разреза с наибольшими вариациями физических свойств горных пород. Искажающее влияние ВЧР проявляется в флуктуациях интенсивности суммарного сигнала и времен прихода отражений, в результате чего на временньгх разрезах возникают дополнительные ложные структурные и амплитудные аномалии [1]. Эти два типа искажений сейсмической записи традиционно устраняют независимо, с привлечением результатов дополнительных исследований.

Применение программ динамического анализа и расчет атрибутов сейсмической затиси предполагает предварительное устранение амплитудных искажений, связанных с различиями условий возбуждения и приема. Эти различия обусловлены цельм рядом причин, и, в первую очередь, неоднородностью ВЧР. Практика сейсморазведочных исследованкй доказывает, что эффект изменения амплитуд регистрируемого сейсмического волнового поля напрямую зависит от того, насколько дифференцирована ВЧР. Поскольку сейсмогеологические параметры слоев горных пород ниже слоя ВЧР менее дифференцированы, то и эффекты ампиитудных изменений отражений от них на несколько порядков слабее (рис.1). Хотя как раз последние изменения и являются полезными искомыми параметрами, дающие возможность судить об изменении вещественного состава пластов.

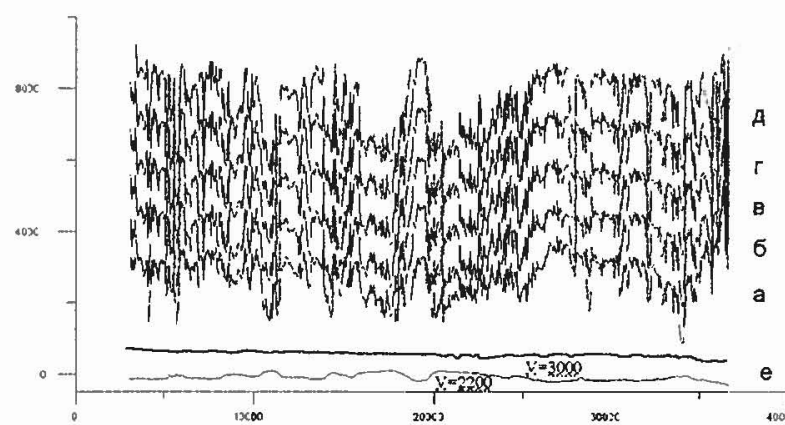

Рис. 1. Модель ВЧР (е) и амптитудные коэффициенты для П피, определенных во временных окнах $1 \mathrm{c}$ с центрами на временах $1.5 \mathrm{c}(\mathrm{a}), 2.0 \mathrm{c}(6), 2.5 \mathrm{c}($ в), $3.0 \mathrm{c}(\mathrm{r}), 3.5 \mathrm{c}$ (д) по трофин $2 Д$.

Статистический динамический анализ с целью устранения негативного влияния ВЧР и получения волнового поля отражений в истинном соотношении амплитуд использует те же принципы и допущения, на которых строятся алгоритмы коррекции статических поправок. При этом, как правило, оперируют со средними значениями амплитуд сейсмической записи в заданном временном интервале для совокупности трасс, объединенным по признакам общего пункта возбуждения, общего пункта приема, общей срединной точки [1]. В силу избыточности данных сейсморазведки ОГТ выделение и выгисление искомых компонент возможно путем решения системы линейных уравнений методом наименьших квадратов.

Существующая прямая связь статических и, главное, динамических поправок со сложным строением ВЧР (рис.2) предъявляет особые требования к динамической обработке сейсморазведочных данньх. Недоучет амплитудных искажений может привести к формированию ложных динамических аномалий, ошибочно интерпретируемых в дальнейшем как аномальное строение пластов геологического разреза.

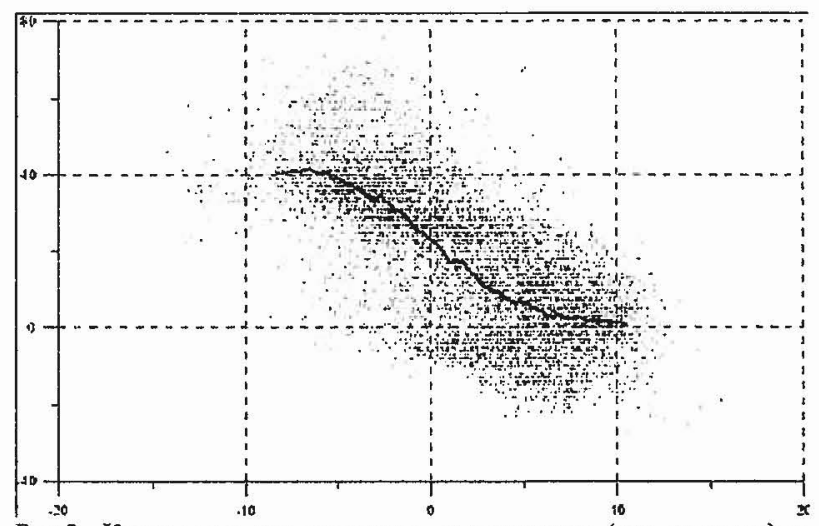

Рис.2. Кросс-плот распределения статических (ось ординат) и амплитудных поправок (ось абсцисс) за ПП на участке съемки 3Д. Красным выделена усредняющая .нния.

Выводы и заключения.

1. На этапе динамической обработки необходимо уделять особое внимание восстановлению истинного соотношения амппитуд, освобожденному от влияния ВЧР.

2. Использовать для вычисления динамических поправок оценку амплитуд сейсмической записи в широком временном окне ниже отражений BपP.

3. На основе корреляционной связи амплитудных и статических поправок возможкно построение итерационного процесса их взаимного утопнения.

4. Для повышения достоверности атрибутивного анализа предпочтительнее использовать дифференциальные оценки амплитуд.

\section{ЛИТЕРАТУРА}

1. Михальцев А.В., Мушин И.А., Погожаев В.М. Обработка динамических параметров в сейсморазведке-- Недра.- Москва.1990. 